\title{
The Impact of Currency Fluctuations on Equity and Debt Market
}

Submitted 28/07/20, 1st revision 11/08/20, 2nd revision 17/09/20, accepted 10/10/20

\begin{abstract}
A. Kotishwar ${ }^{1}$
Abstract:

Purpose: This study attended to investigate the impact of currency fluctuations on equity and debt markets. Furthermore, the study deals with investments in equity considering the currecy as rupee vs. dollar relationship. The European Central Bank has been considered for the external debt market investments considering the euro as the currency. The study mainly focused on the impact of rupee vs. dollar on equity and the euro impact on ECB for debt market investments.

Design/Methodology/Approach: The tools applied are Bivariate Correlation, Ordinary least square method, ARCH model and Vector autoregressive model.

Findings: The study reveals that from 2008 to 2019, the bivariate correlation result indicates that equity investments have a significant relationship with the rupee vs. the dollar. It has been observed that the euro has also a moderate relationship with the debt investments and the OLS result indicated that the euro impact on debt investments is observed to be insignificant. The ARCH result stated that the currency is having a significant effect on the fund's volatility. The VAR estimated that future equity and debt markets are expected to go up shortly.

Practical Implications: The present study result stated that the rupee vs. dollaris having the impact on the equity investments but the euro impact is observed to be insignificant. Therefore, the equity investors should focus more on the rupee vs. dollar fluctuation, so that inflows and outflows of FII funds in to Indian equity market can be identified.

Originality/value: The present study added the scholarly value to the equity markets with regard to the currency fluctuations effect on the equity and debt market investments. The investors of equity and issuers of ECB's investments can consider this study for their decision making.
\end{abstract}

Keywords: Currency, equity, debt market, fluctuations, rupee, dollar.

JEL Codes: F65, G1.

Paper Type: Research article.

ISSN: 2241-4754, H index 10, Q3.

${ }^{1}$ Professor \& Head, Department of Master of Business Administration CMR College of Engineering \& Technology, E-mail: mail2kotish@gmail.com; akotishwar@cmrcet.org; https://orcid.org/0000-0002-8027-3417 


\section{Introduction}

The stock market plays a crucial role in the economic development of any country. The stock market or equity market is a market where the equity instruments are bought and sold of listed companies. Moreover, listed companies are those entities that offer their equity for public offering. Equity can be traded in the primary market where a company makes an Initial Public Offering (IPO), and new securities may be traded. Trading of existing shares can be done in the secondary market. Investors may also own private equity shares of a company that is still private and not listed on the securities market. In order to trade in equities, investors must have a Demat and Trading account. In general equity market is a place where buyers and sellers meet to trade shares. We can observe many stock exchanges around the world, of which they can be physical or virtual. NASDAQ is an example of virtual trading in which stocks are traded electronically by using computer networks. The debt market is a market where investors trade their debt instruments, mostly in bonds.

The Indian debt market is considered as the largest debt market in Asia. In the general debt, the market consists of government securities (state and central) and corporate bonds. In order to meet its spending, the government issues government securities (fixed income instruments), which were originally issued by RBI on behalf of the government. The corporate bonds consist of private sector (PSU) bonds, corporate debentures, etc., usually known as non-government securities. Bonds are considered to be less risky investments for its less volatility compared to equity.

In general, every country has its own currency as Indian currency is denoted in "INR," Switzerland's currency in "Swiss franc," Japan's currency in "yen" and American currency is denoted in "USD," also known as a universal currency. The exchange rate is defined as "The rate at which one currency is exchanged with another currency.' Currency value gets fluctuated, which constantly changes in an exchange rate. Several factors influence currency fluctuations such as the interest rate, inflation rate, political stability, recession, other macroeconomic variables etc. As there is an impact of exchange rate fluctuations on the equity market and debt market, we can say that the stock prices and the exchange rate fluctuations are directly dependent on each other.

\section{Literature Review}

Smita and Saumitra (2019) investigate the effect of cash change on Indian securities exchange by surveying the conversion scale chance during the period 2005-2016, explicitly when budgetary emergencies. Assessing a two-factor exchange valuing model, utilizing an arbitrary coefficient model, the paper presents proof that stock returns respond altogether to outside swapping scale vacillations in the postemergency during the period, 2012-2016. The conversion standard hazard factor is turning into an unmistakable determinant of stock returns, showing that Indian financial specialists are progressively expecting a hazard premium on their 
speculation for their additional presentation to conversion scale chance. The examination additionally verifies this by featuring how higher the remote trade presentation of industry, estimated in terms of professional career balance (net inflows), the higher is their affectability to swapping scale hazard. A conceivable purpose behind such premium could be the deficient support by Indian firms to moderate the conversion scale hazard (Carstina et al., 2015).

Piyali and Anuradha (2018) studied the impact analysis of macroeconomic variables on the stock market. Macroeconomic fundamentals and stock market volatility play an important role in determining and forecasting an economy's future position. In this study, one of the macroeconomic variables, the exchange rate, is studied along with the Indian Stock Market (BSE Index). The linkage between the exchange rate and stock market index is considered an important contributor to predicting any economy's growth/ business cycle. This dynamic linkage between the exchange rate and the stock market has been analyzed considering 15 years of data (from 2010 to 2016) on the exchange rate and stock market index related to the Indian economy. A stock index or stock market index is a measurement of a section of its value. It is computed from the prices of selected stocks (typically a weighted average). It is a tool used by investors and financial managers to describe the market and compare the return on specific investments. The researchers' main focus is to determine the impact of exchange rate fluctuation on stock market volatility to predict India's economic scenario.

The study of Süleyman, Ferhat, and Nuran (2014) examines whether the deviations of monetary standards from their basic qualities influence the connection between financial essentials and trade rates. To this end, a variant of the clingy cost money related to swapping scale model, which associates the trade rates to financial basics. What is more, the model is stretched out by including a two-state time fluctuating change likelihood Markov system exchanging process in which progress between systems is connected to the pace of hazard balanced overabundance returns in the monetary forms. This licenses investigation of the transitional elements of trade rates. Quarterly information of the most dynamic four coasting monetary standards is utilized in the model. These monetary standards are the Australian dollar, the Canadian dollar, the Japanese yen, and the British pound. The outcomes prove that the sharpe proportions of obligation and value interests in the monetary standards impact the advancement of transitional elements of the trade rates' deviation from their basic qualities. As an expansion of this outcome, it was discovered that the connection between monetary basics and the ostensible trade rates are liable to change contingent upon the overvaluation or undervaluation of the monetary forms comparative with their central worth (Thalassinos et al., 2015).

The paper of Divyang and Nikita (2013) analyzes the relationship between exchange $\operatorname{rate}(\$ / ₹)$ and Indian stock exchanges like BSE, NSE. It measures the impact of changes in the exchange rate on Indian stock exchanges like BSE, NSE. Several statistical tests have been applied to measure the exchange rate's impact on Indian 
stock exchanges like correlation, regression, and ANOVA. The study period has been taken for eight years (from January 2005 to December 2012) using daily closing price, and daily prices are converted into the monthly price. From the data analysis, they found that the result of correlation confirmed a negligible relation between exchange rate and nifty and a negligible relationship between the exchange rate and sensex.

However, no study has attempted to examine the impact of currency fluctuations on equity and debt markets. In further research, it should be studied the impact of currency fluctuations on stock markets in India, the impact of exchange rate fluctuation on stock market volatility, the impact of exchange rate fluctuations on the economic growth of India.

\section{Research Objectives}

The research objectives of this study are as follows:

$>$ To study the rupee vs. dollar relationship with equity and debt market investment.

$>$ To examine the currency fluctuations on investment of equity and debt.

$>$ To study the rupee vs. dollar volatility influence on the equity and debt volatility.

$>$ To examine the growth momentum of equity and debt investment based on currency fluctuations.

The research hypotheses of the study are as follows:

Null Hypothesis (H01): There is no relationship between the rupee vs. dollar with equity and debt market investment.

Null Hypothesis (H02): There is no influence of currency fluctuations on investments in equity and debt.

Null Hypothesis (H03): There is no influence of rupee vs. dollar volatility on equity and debt volatility.

\section{Research Methodology}

The present study has been emphasized in secondary data using descriptive statistical tools. The following variables and methods have been considered:

Bivariate Correlation: The bivariate correlation has been applied to know the relationship between the two variables, i.e., currency with the equity and debt market investments.

Ordinary Least Square method: The study applied the OLS to know the impact of currency fluctuation on the equity and debt market investments.

ARCH model: The study applied the ARCH family models to know the volatility of 
the equity and debt market benchmark with the currency fluctuations.

Vector autoregressive model: The study applied the VAR model to know the future direction based on the vector autoregression model. The equity and debt market investment direction has been identified based on the currency fluctuations in the study.

This study deals with 10 years in the period from 1st January 2008 to 31st March 2019 considering currency fluctuations and external commercial borrowings influence on equity and debt market.

\section{Hypotheses Testing}

Null hypothesis: There is no significant relationship between the euro with debt investment.

Alternate hypothesis: There is a significant relationship between the euro with debt investment.

Table 1. Relationship of Currency with Debt Investment

\begin{tabular}{|c|c|c|c|}
\hline & USD & Debt \\
\hline \multirow[t]{3}{*}{ Euro } & Pearson Correlation & 1 & $-.521^{* *}$ \\
\hline & Sig. (2-tailed) & & .000 \\
\hline & $\mathrm{N}$ & 243 & 111 \\
\hline \multirow[t]{3}{*}{ Debt } & Pearson Correlation & $-.521^{* *}$ & 1 \\
\hline & Sig. (2-tailed) & .000 & \\
\hline & $\mathrm{N}$ & 111 & 111 \\
\hline
\end{tabular}

Note:** Correlation is significant at the 0.01 level (2-tailed).

Source: Compiled data.

Table 1 reveals that debt narket investment with euro (-0.521) has a negatively moderate relationship. The probability value is observed to be less than 0.05 , which indicates the rejection of the null hypothesis and the acceptance of the alternate hypothesis.

Null hypothesis: There is no significant relationship between the rupee vs. dollar with equity investment.

Alternate hypothesis: There is a significant relationship between the rupee vs dollar with equity investment.

Table 2. Relationship between Currency and Equity Investment

\begin{tabular}{|l|l|l|l|}
\hline \multicolumn{2}{|l|}{ Correlation } & USD & Equity \\
\hline \multirow{3}{*}{ USD } & Pearson Correlation & 1 & $.900^{* *}$ \\
\cline { 2 - 4 } & Sig. (2-tailed) & & .000 \\
\cline { 2 - 4 } & $\mathrm{N}$ & 243 & 111 \\
\hline Equity & Pearson Correlation & $.900^{* *}$ & 1 \\
\hline
\end{tabular}




\begin{tabular}{|l|l|l|l|}
\hline & Sig. (2-tailed) & .000 & \\
\cline { 2 - 4 } & $\mathrm{N}$ & 111 & 111 \\
\hline
\end{tabular}

\section{Source: Compiled data.}

Table 2 shows that equity investments with rupee vs. dollar (0.900) has a positive strong relationship. The probability value is less than 0.05 , which indicates the rejection of the null hypothesis and the acceptance of the alternate hypothesis.

Null hypothesis: There is an insignificant impact of currency fluctuations on equity investment.

Alternate hypothesis: There is a significant impact of currency fluctuations on equity investment.

Table 3. Influence of Currency Fluctuations on Equity Investment

\begin{tabular}{|c|c|c|c|c|}
\hline \multicolumn{5}{|c|}{ Dependent Variable: EQUITY INVESTMENT } \\
\hline \multicolumn{5}{|c|}{ Method: Least Squares } \\
\hline \multicolumn{5}{|c|}{ Sample (adjusted): 1109} \\
\hline \multicolumn{5}{|c|}{ Included observations: 105 after adjustments } \\
\hline Variable & Coefficient & Std. Error & t-Statistic & Prob. \\
\hline $\mathrm{C}$ & 0.680796 & 0.470129 & 1.448104 & 0.0006 \\
\hline Rupee vs. dollar & 0.003206 & 0.004047 & 0.792232 & 0.0001 \\
\hline R-squared & 0.605736 & \multicolumn{2}{|c|}{ Mean dependent var } & 0.802147 \\
\hline Adjusted R-squared & 0.003593 & \multicolumn{2}{|c|}{ S.D. dependent var } & 4.546353 \\
\hline S.E. of regression & 4.554514 & \multicolumn{2}{|c|}{ Akaike info criterion } & 5.888979 \\
\hline Sum squared resid & 2136.591 & \multicolumn{2}{|c|}{ Schwarz criterion } & 5.939530 \\
\hline Log likelihood & 307.1714 & \multirow{2}{*}{\multicolumn{2}{|c|}{ Hannan-Quinn criter. }} & 5.909463 \\
\hline F-statistic & 0.627631 & & & 2.035668 \\
\hline Prob(F-statistic) & 0.430047 & & & \\
\hline
\end{tabular}

Source: Compiled data.

Table 3 shows that equity investment coefficient value is 0.0032 , which indicates that rupee vs. dollar is having a positive influence on equity investment. The further probability value is observed to be statistically significant at 5\% level. The Rsquared is 0.60 , which indicates that the model is strongly fitted. Hence it is concluded that reject the null hypothesis and accept the alternate hypothesis. i.e., there is a significant impact of currency fluctuation on equity investment.

Null hypothesis: There is an insignificant impact of currency fluctuations on debt investment.

Alternate hypothesis: There is a significant impact of currency fluctuations on debt investment.

Table 4. The Influence of Currency Fluctuations on Debt Investment 


\begin{tabular}{|l|l|l|l|l|}
\hline \multicolumn{4}{|l|}{ Sample (adjusted): 1109} & \\
\hline \multicolumn{4}{|l|}{ Included observations: 105 after adjustments } \\
\hline Variable & Coefficient Std. Error & Std error & t-Statistic & Prob. \\
\hline C & 0.010504 & 0.112288 & 0.093546 & 0.9257 \\
\hline Euro & 0.231602 & 0.000967 & 0.622369 & 0.5351 \\
\hline R-squared & 0.333747 & Mean dependent var & 0.033274 \\
\hline Adjusted R-squared & -0.215926 & S.D. dependent var & 1.084617 \\
\hline S.E. of regression & 1.087825 & Akaike info criterion & 3.025102 \\
\hline Sum squared resid & 121.8865 & Schwarz criterion & 3.075654 \\
\hline Log likelihood & -156.8179 & Hannan-Quinn criter. & 3.045587 \\
\hline F-statistic & 0.387344 & Durbin-Watson stat & 1.237893 \\
\hline Prob(F-statistic) & 0.535074 & \multicolumn{3}{|l}{} \\
\hline Sourc: Compied & \multicolumn{3}{|l}{} \\
\hline
\end{tabular}

Source: Compiled data.

The study applied the ordinary Least Square method to examine the euro on debt market investments. The study result stated that debt's coefficient value (0.2316) has a positive influence on debt investment. The further probability value is observed to be statistically insignificant at $5 \%$ level. R-squared is 0.3337 , which indicates that the model is moderately fitted. Hence it is concluded that reject the alternate hypothesis and accept the null hypothesis. i.e., there is an insignificant impact of currency fluctuation on debt investment.

The following hypothesis has been framed to examine the objectives with the ARCH family models.

Null hypothesis: ARCH effect does not exist between the rupee vs. dollar volatility on equity investment.

Alternate hypothesis: ARCH model effect exists between the volatility of the rupee vs. dollar on equity investment.

Table 5. Heteroskedasticity Test: ARCH

\begin{tabular}{|l|l|l|l|}
\hline Test & & & Sig. \\
\hline F-statistic & 10.11738 & Prob. F(1,106) & 0.0013 \\
\hline Obs*R-squared & 0.787711 & Prob. Chi-Square(1) & 0.0011 \\
\hline
\end{tabular}

Source: Compiled data.

Table 5 indicates the volatility effect on rupee vs. dollar on equity investment. The results show that F-statistic value is observed to be greater than the critical value (i.e., $10.117>2.803$ ), and the probability value seems to be less than 0.005 , which signifies rejection of the null hypothesis accepting the alternate hypothesis, i.e., $\mathrm{ARCH}$ effects exist between the volatility of rupee vs. dollar on equity investment. 
Figure 1. Residual Graph

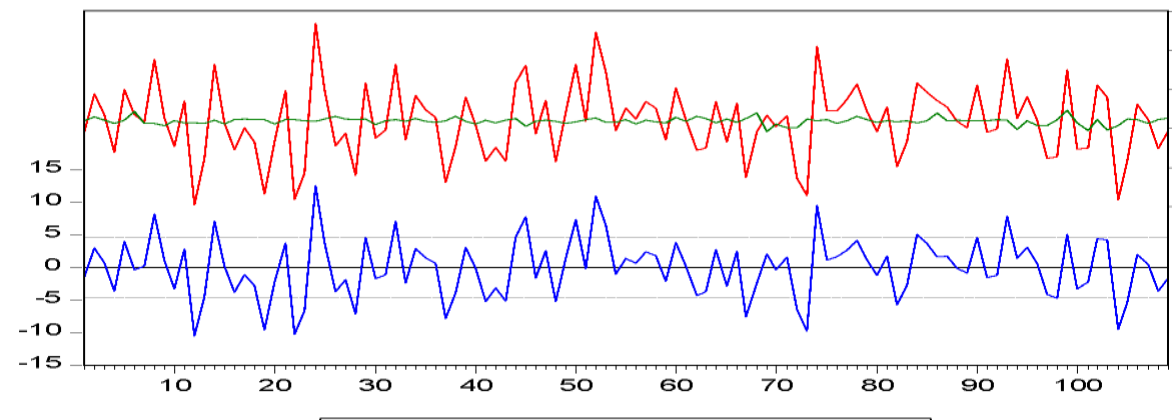

Source: Compiled data.

The above graph represents the volatility of the rupee vs. dollar influence on the volatility of equity investment. Here the plotted lines cross the fitted lines, and the long clusters are forming. Hence the GARCH model is estimated to evaluate the volatility influence of rupee vs. dollar equity investment.

Table 6. GARCH effect of Rupee Vs Dollar on Equity Investment

\begin{tabular}{|c|c|c|c|c|}
\hline \multicolumn{5}{|c|}{ Dependent Variable: EQUITY } \\
\hline \multicolumn{5}{|c|}{ Method: ML ARCH - Normal distribution (BFGS / Marquardt steps) } \\
\hline \multicolumn{5}{|c|}{ Sample (adjusted): 1109} \\
\hline \multicolumn{5}{|c|}{ Included observations: 109 after adjustments } \\
\hline \multicolumn{5}{|c|}{ Convergence achieved after 24 iterations } \\
\hline \multicolumn{5}{|c|}{ Coefficient covariance computed using outer product of gradients } \\
\hline \multicolumn{5}{|c|}{ Presample variance: backcast (parameter $=0.7$ ) } \\
\hline \multicolumn{5}{|c|}{$\mathrm{GARCH}=\mathrm{C}(3)+\mathrm{C}(4) * \mathrm{RESID}(-1)^{\wedge} 2+\mathrm{C}(5) * \mathrm{GARCH}(-1)$} \\
\hline Variable & Coefficient & Std. Error & z-Statistic & Prob. \\
\hline $\mathrm{C}$ & 1.029162 & 0.460778 & 2.233534 & 0.0255 \\
\hline \multirow[t]{2}{*}{ RVSD } & 0.205178 & 0.221068 & 0.928122 & 0.0033 \\
\hline & \multicolumn{2}{|c|}{ Variance Equation } & & \\
\hline $\mathrm{C}$ & 4.156273 & 8.290308 & 0.501341 & 0.6161 \\
\hline $\operatorname{RESID}(-1)^{\wedge} 2$ & 0.019520 & 0.071657 & 0.272404 & 0.7853 \\
\hline GARCH(-1) & 0.786105 & 0.437637 & 1.796247 & 0.0725 \\
\hline R-squared & 0.007937 & \multicolumn{2}{|c|}{ Mean dependent var } & 0.910332 \\
\hline Adjusted R-squared & -0.001335 & \multicolumn{2}{|c|}{ S.D. dependent var } & 4.608969 \\
\hline S.E. of regression & 4.612043 & \multicolumn{2}{|c|}{ Akaike info criterion } & 5.955725 \\
\hline Sum squared resid & 2275.991 & \multicolumn{2}{|c|}{ Schwarz criterion } & 6.079181 \\
\hline Log likelihood & -319.5870 & \multicolumn{2}{|c|}{ Hannan-Quinn criter. } & 6.005791 \\
\hline Durbin-Watson stat & 1.979336 & & & \\
\hline
\end{tabular}

Source: Compiled data.

Table 6 reveals the GARCH effect of rupee vs. dollar on equity investment. The result shows that the rupee vs. dollar coefficient value is 0.205178 which indicates that the volatility of rupee vs. dollar is having a positive influence on equity investment. The probability value is observed to be statistically significant at $5 \%$ 
level. Hence, it is concluded that volatility influence exists between the rupee vs. dollar on equity investment.

Null hypothesis: ARCH model effect does not exist between the euro's volatility on debt investment.

Alternate hypothesis: ARCH model effect exists between the euro's volatility vs. dollar on debt investment.

Table 7. Heteroskedasticity Test: ARCH

\begin{tabular}{|l|l|l|l|}
\hline F-statistic & 12.189183 & Prob. F(1,107) & 0.0019 \\
\hline Obs*R-squared & 2.185390 & Prob. Chi-Square(1) & 0.0013 \\
\hline
\end{tabular}

Source: Compiled data.

In Table 7 the heteroskedacity test indicates the volatility effect of euro on debt investment. The results show that F-statistic value is observed to be greater than the critical value (i.e., $12.189>2.803$ ), and the probability value seems to be less than 0.005 , which signifies rejection of the null hypothesis and acceptance of the alternate hypothesis, i.e., ARCH effects exist between the volatility of Euro on debt investment.

Figure 2. Residual Graph

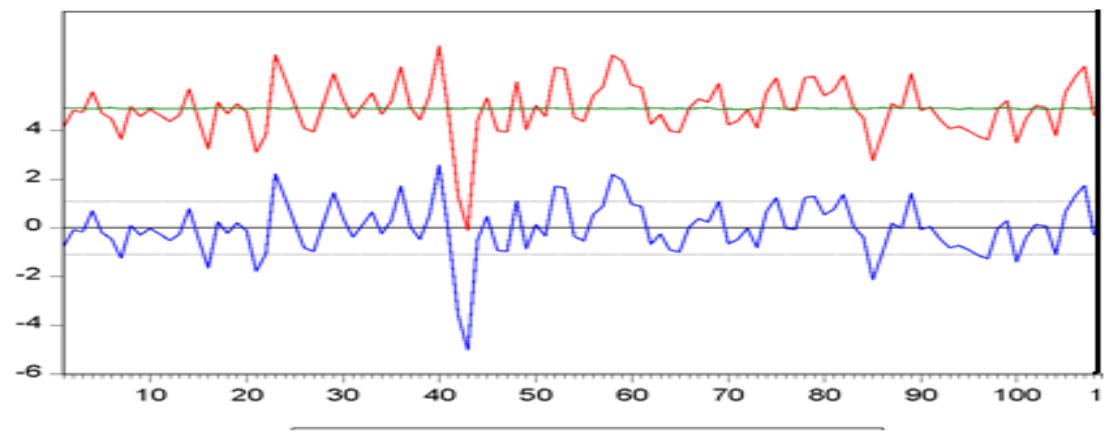

Source: Compiled data.

The above graph represents the volatility of the Euro influence on the volatility of equity investment. The plotted lines cross the fitted lines, and the long clusters are forming. Hence the GARCH model is estimated to evaluate the volatility influence of rupee vs. dollar on debt investment.

Table 8. The GARCH effect of Euro on Debt Investment

\begin{tabular}{|l|}
\hline Dependent Variable: DEBT \\
\hline Method: ML ARCH - Normal distribution (BFGS / Marquardt steps) \\
\hline Sample (adjusted): 1110 \\
\hline Included observations: 110 after adjustments \\
\hline Convergence achieved after 27 iterations \\
\hline Coefficient covariance computed using outer product of gradients \\
\hline Presample variance: backcast (parameter $=0.7$ ) \\
\hline
\end{tabular}




\begin{tabular}{|c|c|c|c|c|}
\hline \multicolumn{5}{|c|}{ GARCH $=\mathrm{C}(3)+\mathrm{C}(4)^{*} \mathrm{RESID}(-1)^{\wedge} 2+\mathrm{C}(5)^{*} \mathrm{GARCH}(-1)$} \\
\hline Variable & Coefficient & Std. Error & z-Statistic & Prob. \\
\hline $\mathrm{C}$ & 0.041786 & 0.104515 & 0.399811 & 0.6893 \\
\hline \multirow[t]{2}{*}{ RVSD } & 0.111565 & 0.052334 & 0.220978 & 0.0051 \\
\hline & \multicolumn{2}{|c|}{ Variance Equation } & & \\
\hline $\mathrm{C}$ & 0.507258 & 0.287746 & 1.762871 & 0.0779 \\
\hline RESID $(-1)^{\wedge} 2$ & 0.226421 & 0.101688 & 2.226632 & 0.0260 \\
\hline GARCH(-1) & 0.312680 & 0.278333 & 1.123403 & 0.2613 \\
\hline R-squared & -0.000275 & \multicolumn{2}{|c|}{ Mean dependent var } & 0.031143 \\
\hline Adjusted R-squared & -0.009537 & \multicolumn{2}{|c|}{ S.D. dependent var } & 1.080201 \\
\hline S.E. of regression & 1.085340 & \multicolumn{2}{|c|}{ Akaike info criterion } & 2.951756 \\
\hline Sum squared resid & 127.2200 & \multicolumn{2}{|c|}{ Schwarz criterion } & 3.074505 \\
\hline Log likelihood & -157.3466 & \multicolumn{2}{|c|}{ Hannan-Quinn criter. } & 3.001543 \\
\hline Durbin-Watson stat & 1.231143 & & & \\
\hline
\end{tabular}

Source: Compiled data.

Table 8 represents the GARCH effect of rupee vs. dollar on debt investment. The result shows that the rupee vs. dollar coefficient value is 0.111565 which indicates that the rupee vs. dollar volatility is having a negative influence on debt investment. The probability value is observed to be statistically insignificant at $5 \%$ level. Hence, it is concluded that volatility influence does not exist between the rupee vs. dollar on debt investment.

Table 9. Depicts the Lag Order Selection Criteria for Rupee Vs. Dollar with Equity Investment

\begin{tabular}{|c|c|c|c|c|c|c|}
\hline \multicolumn{7}{|c|}{ VAR Lag Order Selection Criteria } \\
\hline \multicolumn{7}{|c|}{ Endogenous variables: RVSD EQUITY } \\
\hline \multicolumn{7}{|c|}{ Exogenous variables: $\mathrm{C}$} \\
\hline \multicolumn{7}{|c|}{ Sample: 1112} \\
\hline \multicolumn{7}{|c|}{ Included observations: 101} \\
\hline Lag & $\operatorname{LogL}$ & LR & FPE & AIC & $\mathrm{SC}$ & HQ \\
\hline 0 & -523.7614 & NA & 113.9049 & 10.41112 & 10.46291 & 8 \\
\hline 1 & -519.0985 & $9.048713^{*}$ & 112.4234 & 10.39799 & 10.55334 & $10.46088^{*}$ \\
\hline 2 & -514.8698 & 8.038883 & $111.9294 *$ & $10.39346^{*}$ & $10.65238^{*}$ & 10.49828 \\
\hline 3 & -511.8960 & 5.535390 & 114.2595 & 10.41378 & 10.77627 & 10.56053 \\
\hline 4 & -510.2286 & 3.037536 & 119.7213 & 10.45997 & 10.92603 & 10.64865 \\
\hline 5 & -506.9363 & 5.867421 & 121.5065 & 10.47399 & 11.04362 & 10.70459 \\
\hline 6 & -506.0313 & 1.577158 & 129.3330 & 10.53527 & 11.20847 & 10.80780 \\
\hline 7 & -504.7553 & 2.173001 & 136.7132 & 10.58921 & 11.36598 & 10.90367 \\
\hline 8 & -502.3593 & 3.985430 & 141.4137 & 10.62098 & 11.50131 & 10.97736 \\
\hline \multicolumn{7}{|c|}{$*$ indicates lag order selected by the criterion } \\
\hline \multicolumn{7}{|c|}{ LR: sequential modified LR test statistic (each test at 5\% level) } \\
\hline \multicolumn{7}{|c|}{ FPE: Final prediction error } \\
\hline \multicolumn{7}{|c|}{ AIC: Akaike information criterion } \\
\hline \multicolumn{7}{|c|}{ SC: Schwarz information criterion } \\
\hline
\end{tabular}

Source: Compiled data.

Table 9 depicts that the Lag order selection criteria for rupee vs. dollar with equity investment. Here the LR test seems to be fit at Lag1, whereas the final prediction 
error is observed to be fited at Lag 2. Criteria such as the Akaike information criterion and Schwarz information criterion at Lag 2 and Hannan-Quinn information criterion seems to be fitted at Lag 1 . Hence, most of the criteria are fitted at Lag 2, which concludes the Lag 2 is an optimum model to evaluate VAR concerning rupee vs dollar on equity.

Table 10. Vector Autoregression Estimates

\begin{tabular}{|l|l|}
\hline \multicolumn{2}{|l|}{ Sample (adjusted): 3109} \\
\hline \multicolumn{2}{|l|}{ Included observations: 107 after Adjustments } \\
\hline Standard errors in ( ) \& t-statistics in [ ] \\
\hline & RVSD \\
\hline RVSD(-1) & 0.019626 \\
\hline & $(0.09849)$ \\
\hline & {$[0.19926]$} \\
\hline RVSD(-2) & -0.120799 \\
\hline & $(0.09744)$ \\
\hline C & {$[-1.23970]$} \\
\hline & -0.463073 \\
\hline & $0.23539)$ \\
\hline EQUITY & {$[-1.96727]$} \\
\hline & 0.036539 \\
\hline & $0.04936)$ \\
\hline R-squared & {$[0.74028]$} \\
\hline Adj. R-squared & 0.021762 \\
\hline Sum sq. resids & -0.006730 \\
\hline S.E. equation & 555.1692 \\
\hline F-statistic & 2.321636 \\
\hline Log likelihood & 0.763798 \\
\hline Akaike AIC & -239.9112 \\
\hline Schwarz SC & 4.559088 \\
\hline
\end{tabular}

\section{Source: Compiled data.}

Table 10 represents that dependent variable as an equity investment and independent as rupee vs. the dollar. The result shows that the regression weights of equity are observed to be positive. Hence, it is concluded that the model is used to estimate involve root test of rupee vs. dollar on equity investment.

Figure 3. Inverse Roots of AR Characteristic Polynom

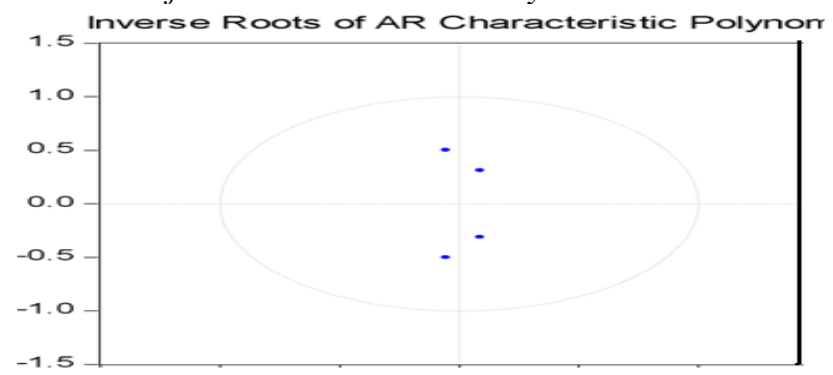

\section{Source: Compiled data.}


The figure above represents the polynomial distribution of rupee vs. dollar on equity investment. Here the plotted dot is observed to be falling inside the circle, which indicates that the data is polynomial distributed. Hence, it is concluded that the rupee vs. dollar's future growth is having a significant impact of growth on equity investment.

Table 11. The Lag order selection criteria for Euro with Debt Investment

\begin{tabular}{|c|c|c|c|c|c|c|}
\hline \multicolumn{7}{|c|}{ VAR Lag Order Selection Criteria } \\
\hline \multicolumn{7}{|c|}{ Endogenous variables: RVSD DEBT } \\
\hline \multicolumn{7}{|c|}{ Exogenous variables: $\mathrm{C}$} \\
\hline \multicolumn{7}{|c|}{ Sample: 1112} \\
\hline \multicolumn{7}{|c|}{ Included observations: 102} \\
\hline Lag & $\log \mathrm{L}$ & LR & FPE & AIC & $\mathrm{SC}$ & HQ \\
\hline 0 & -382.4836 & NA & 6.443944 & 7.538894 & 7.590364 & 7.559736 \\
\hline 1 & -371.0549 & 22.18509 & 5.570657 & 7.393233 & $7.547643^{*}$ & 7.455759 \\
\hline 2 & -364.8728 & $11.75801 *$ & $5.338000^{*}$ & $7.350448^{*}$ & 7.607798 & $7.454658 *$ \\
\hline 3 & -363.8790 & 1.851214 & 5.663663 & 7.409393 & 7.769683 & 7.555287 \\
\hline 4 & -360.8092 & 5.597919 & 5.770725 & 7.427632 & 7.890862 & 7.615209 \\
\hline 5 & -357.8161 & 5.340674 & 5.890284 & 7.447374 & 8.013545 & 7.676636 \\
\hline 6 & -355.7831 & 3.547756 & 6.128663 & 7.485943 & 8.155054 & 7.756889 \\
\hline 7 & -354.6516 & 1.930128 & 6.493044 & 7.542189 & 8.314240 & 7.854819 \\
\hline 8 & -352.4455 & 3.676921 & 6.738830 & 7.577363 & 8.452354 & 7.931676 \\
\hline \multicolumn{7}{|c|}{ * indicates lag order selected by the criterion } \\
\hline \multicolumn{7}{|c|}{ LR: sequential modified LR test statistic (each test at 5\% level) } \\
\hline \multicolumn{7}{|c|}{ FPE: Final prediction error } \\
\hline \multicolumn{7}{|c|}{ AIC: Akaike information criterion } \\
\hline \multicolumn{7}{|c|}{ SC: Schwarz information criterion } \\
\hline
\end{tabular}

Source: Compiled data.

Teble 11 depicts the Lag order selection criteria for Euro with debt investment. Here the LR test and final prediction error and Akaike information criterion seem to be fitted at Lag 2. Schwarz information criterion observed at Lag 1 and Hannan-Quinn information criterion seems to be fitted at Lag 2. Hence, most of the criterions are fitted at Lag 2 which concludes the Lag 2 is an optimum model to evaluate VAR with respect to rupee vs dollar on debt.

Table 12: Vector Auto Regression Estimates

\begin{tabular}{|l|l|}
\hline \multicolumn{2}{|l|}{ Sample (adjusted): 3110} \\
\hline \multicolumn{2}{|l|}{ Included observations: 108 after } \\
\hline Adjustments \\
\hline Standard errors in ( ) \& t-statistics in [ ] \\
\hline & RVSD \\
\hline RVSD(-1) & 0.035999 \\
\hline & $(0.09830)$ \\
\hline & {$[0.36620]$} \\
\hline RVSD(-2) & -0.122709 \\
\hline & $(0.09726)$ \\
\hline & {$[-1.26165]$} \\
\hline C & -0.410060 \\
\hline
\end{tabular}




\section{Source: Compiled data.}

\begin{tabular}{|l|c|}
\hline & $(0.22960)$ \\
\hline & {$[-1.78600]$} \\
\hline BOND & 0.016457 \\
\hline & $(0.20958)$ \\
\hline & {$[0.07853]$} \\
\hline R-squared & 0.016211 \\
\hline Adj. R-squared & -0.012167 \\
\hline Sum sq. resids & 560.9032 \\
\hline S.E. equation & 2.322348 \\
\hline F-statistic & 0.571259 \\
\hline Log likelihood & -242.2059 \\
\hline Akaike AIC & 4.559368 \\
\hline Schwarz SC & 4.658707 \\
\hline Mean dependent & -0.375923 \\
\hline S.D. dependent & 2.308348 \\
\hline
\end{tabular}

Table 12 represents the dependent variable as debt investment and independent as euro. The results show that the regression weights of debt are observed to be positive. Hence, it is concluded that the model is used to estimate involve root test of rupee vs. dollar on debt investment.

Figure 4. Inverse Roots of AR Characteristic Polynom

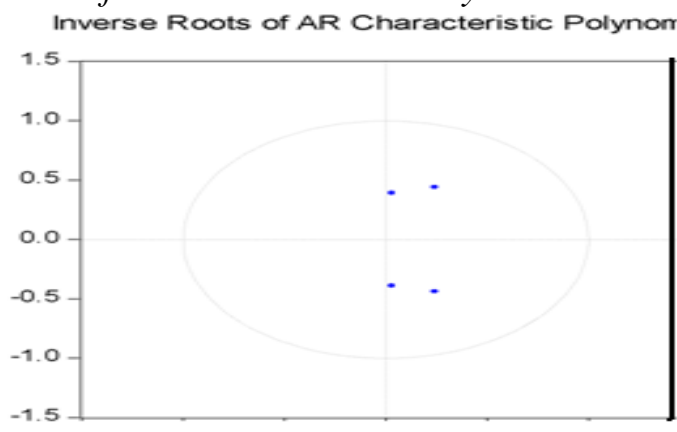

Source: Compiled data.

The above graph represents the polynomial distribution of euro on debt investment. Here the plotted dot is observed to be falling inside the circle, which indicates that the data is polynomial distributed. Hence, it is concluded that the rupee vs. dollar's future growth is having a significant impact on growth on debt investment.

\section{Stady Findings}

The following findings have been derived based on the framed four objectives with various statistical methods. They are as follows:

The study concludes that rupee vs. dollar is correlated strongly with equity investment $(\mathrm{r}=0.900)$. 
$>$ Correlated test found that debt investment seems to be negative and moderately correlated with euro currency.

$>$ The study found that ECB had significantly influenced the equity market and debt market and stated that ECB on the debt market is influenced on the equity market.

$>$ The study synchronized that equity and debt investment volatility has a significant ARCH effect on rupee vs. dollar fluctuation.

$>$ The study showed that equity investment and debt investment significantly affect the currency fluctuation in which the equity market had superior influence than the debt market investment.

\section{Suggestions}

The study observed that the investors of equity and debt market should focus more on the euro appreciation and depreciation so that the investments will be protected. The study suggests to the FII's of equity and debt market to be cautious with the Indian regulations, which will affect their decision significantly. The study advised the regulators to ease the norms to attract the investors and exporters and importers into India so that investments will increase and create employment.

\section{Conclusion}

The present study concludes that the currency influence fund flows into India from 2000 to 2018. The analysis has considered the equity and debt market. In the study, external commercial borrowings have been considered. The FII data has been taken into consideration in the equity segment. The rupees vs. dollar and euro currencies were considered in the study. The study aims to know the currency fluctuation impact on the funds which are coming into India. The study observed that the bivariate correlation result indicates that equity investments have a significant relationship with the rupee vs. dollar. The euro has a moderate relationship as it has been observed with the debt market investments.

The OLS result indicated that the ECB has a significant impact on the equity and debt market investments. The ARCH result stated that the currency is having a significant effect on the fund's volatility. The VAR estimated that in the future, equity and debt markets are expected to go up shortly. The euro currency influence has been observed positively on all selected external flows into India. Hence there is a need to research this area by considering various external and internal economic factors so that currency influence on the fund flows can be managed efficiently.

\section{References:}

Carstina, S., Siminica, M., Circiumaru, D., Bandoi, A. 2015. Country Risk Decision-Maker in Applying the Yield Cash-Flow Estimate. International Journal of Economics and Business Administration, 3(1), 79-89, RePEc:ers:ijebaa:v:iii:y:2015:i:1:p:79-89. 
Divyang, P., Nikita, K. 2013. The Impact of Exchange Rate on Indian Stock Exchanges like BSE \& NSE. International Journal of Scientific Research, 2(10), 1-2.

Jibumon, K.G. 2013. The impact of exchange rate fluctuation on NIFTY 50 with special reference to Dollar, Euro, and British Pound. International Journal of Management Studies, 4(6), 120-125.

Piyali, R.C., Anuradha, A. 2018. Impact of exchange rate fluctuation on stock market Volatility: A study to predict the economic scenario in India. International Journal of Pure and Applied Mathematics,118(18), 4309-4316.

Smita, M., Saumitra, N.B. 2019. Dynamics of the impact of currency fluctuations on stock markets in India: Assessing the pricing of exchange rate risks, Borsa Istanbul Review, Research and Business Development Department, Borsa Istanbul, vol. 19(1).

Süleyman, H., Ferhat, A., Nuran, A. 2014. Bond Markets, Stock Markets and Exchange Rates: A Dynamic Relationship. Research Department of Borsa İstanbul, Working Paper Series, 11.

Thalassinos, I.E., Ugurlu, E. and Muratoglu, Y. 2015. Comparison of Forecasting Volatility in the Czech Republic Stock Market. Applied Economics and Finance, 2(1), 11-18, DOI:10.11114/aef.v2i1.608. 